\title{
Electroencephalographic Finds - EEG According To 13 Cases of Patients Who Are Cocaine Chronic Users In Comparison To A Healthy Control Group of 10 Patients With Similar Characteristics
}

\author{
*Sandra López Carrillo, *Ángel Molina León, Ramón Sobrino Torrens, María Pilar Egea Cegarra, Juana María \\ Pagán Sánchez, Carmen Rodenas Meca and Aharon Franco Giménez Psicólogo Clínico \\ Doctors and nurses the clinic neurophysiology service, Spain
}

Submission: January 23, 2017; Published: February 02, 2017

*Corresponding author: Ángel Molina León and Sandra López Carrillo, Doctors and nurses the clinic neurophysiology service, Santa Lucia Hospital, Cartagena, Murcia, Spain, Email: molinadelaasuncion@gmail.com

\begin{abstract}
In chronic cocaine users, dysfunctional and structural findings have been found, the etiology of this dysfunction is unknown. In our group of patients MRI was completely normal and we have described a mild dysfunctional anomaly in the frontal cortex that is common denominator in this type of patients. The aim of this study is to investigate the cortical EEG activity of these patients. The question we ask is the following is cocaine which generates a dysfunctional disorder in the cortex of these patients or on the contrary on slightly dysfunctional brain the patient get into consumption of toxic.
\end{abstract}

Keywords: Cocaine; EEG; Frontal; Dysfunctional lesion; Slowing; Brain; Electroencephalogram; Cerebral areas; Drugs

\section{Introduction}

The frontal lobe is in charge of complex cognitive processes, called executive functions. These functions are mental operations which go to an end and allow a behavioral control, that is to say, they make possible that we can choose, plan and take voluntary and conscious decisions. The prefrontal cortex has the decisive role in the executive functions by integrating the information and allowing the choice of objectives and the organization of the action plans to do them. It constitutes a cerebral region which is one of the most philogenetically recent and also it is the last one to mature in the ontogenesis, the most developed in the evolutionary scale [1]. It is also involved in the socialemotional processing and control, in the cooperative work. Its responsibility in frontal functions is caused to his conexión with the amígdala (which interferes in the memory) and motivation system (limbic system) and dopamine gratification. Self-control is an important function of the frontal lobe.

Cocaine effect in the brain: within the normal process of communication, neurons release dopamine inside of the synapses, where it joins to dopamine receptors in adjacent neurons. Normally, a specialized protein called "transporter of dopamine" recycles the dopamine by returning to the transmitting neuron. When cocaine has been consumed, this one is adhered to the transporter protein of dopamine and blocks the normal process of recycling, resulting in an accumulation of dopamine in the synapses, which magnifies or exaggerates the pleasurable effects of cocaine (Figure 1).

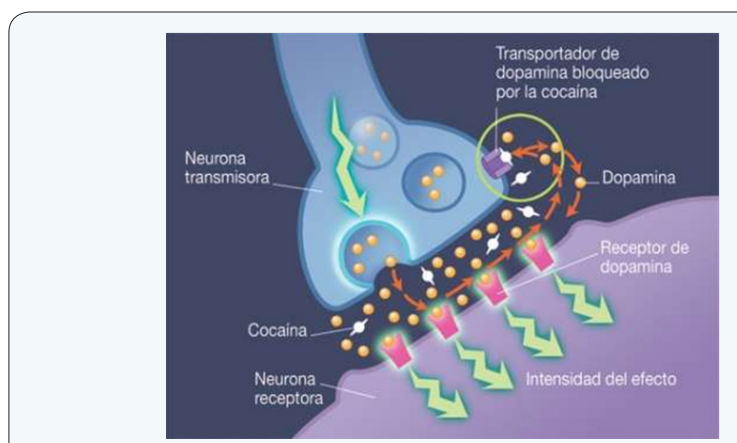

Figure 1: Cocaine effect in the brain.

\section{Methods and material}

We conducted a descriptive, longitudinal and retrospective study. It consists of the morphological electroencephalographic (EEG) analysis of 13 patients who are cocaine users in comparison 
to 10 healthy patients' non cocaine users. 23 revisions EEG have been studied [2-7].

\section{Objectives}

Determine EEG alterations that chronic patients have (more than 1 year) in comparison to the patients who are not cocaine users. Identify the brain areas involved in the EEG of patients who consume cocaine. Try to prove the existence or not of structural or criptogenic lesions, or on the contrary the Clinical Case Results existence of a minimal cortical dysfunction in patients who are addicted to cocaine.

The main objective in our study is to determine if on a normal brain cocaine induces minimal structural or/and dysfunctional changes, and if these lesions in the frontal lobe could be the cause or the consequence of the cocaine habit. See if the EEG really demonstrates the existence of dysfunctional cortical or not [7-11].

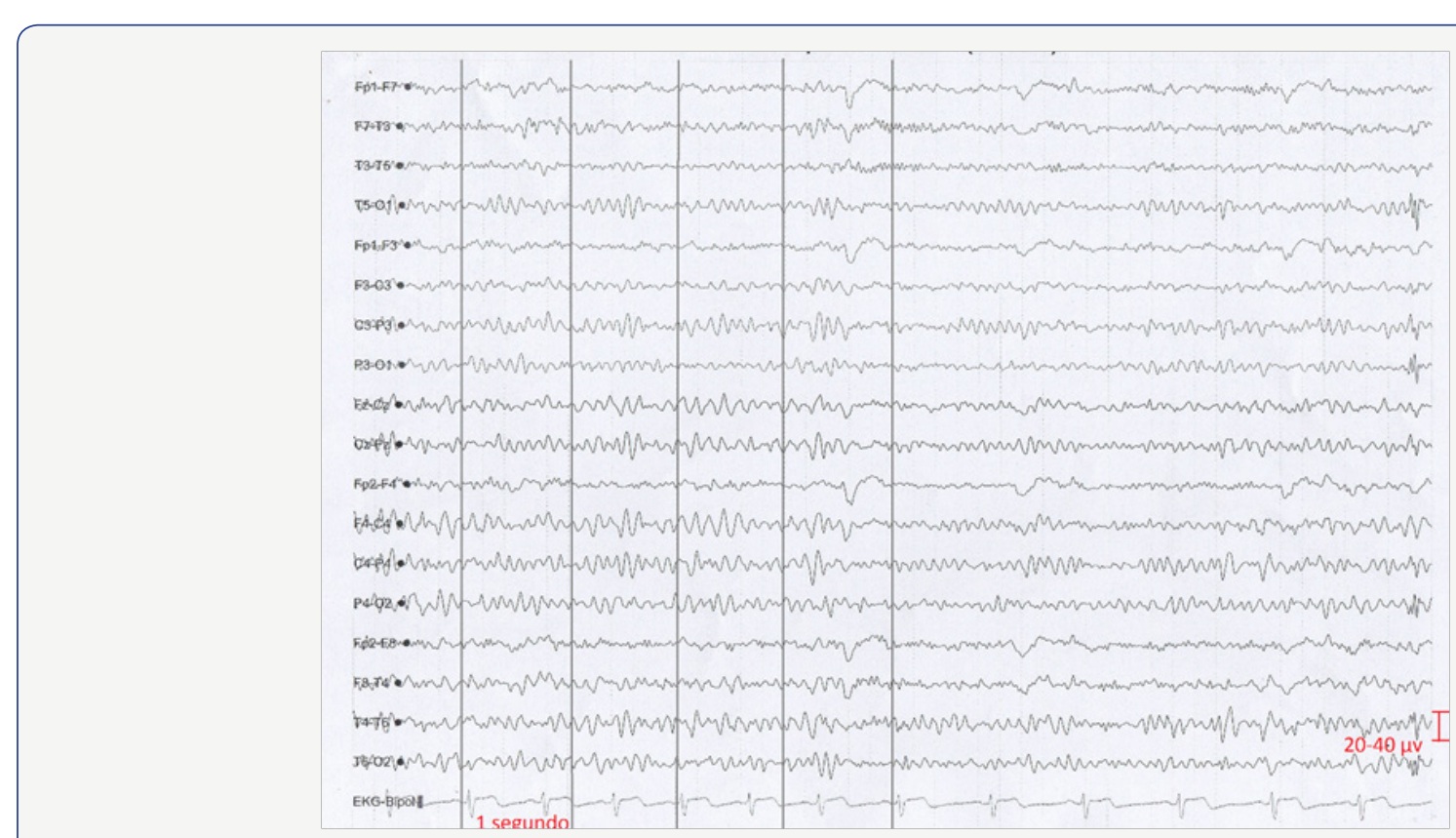

Figure 2: High filter: $30 \mathrm{~Hz}$. Low filter: $0.5 \mathrm{~Hz}$.

Sweep: 10 milliseconds. 10 seconds per screen. Sensitivity 7 microvolts.
I. Clinical case 1: normal EEG (Figure 2) See the absence of specific inter hemispheric calculable anomalies.

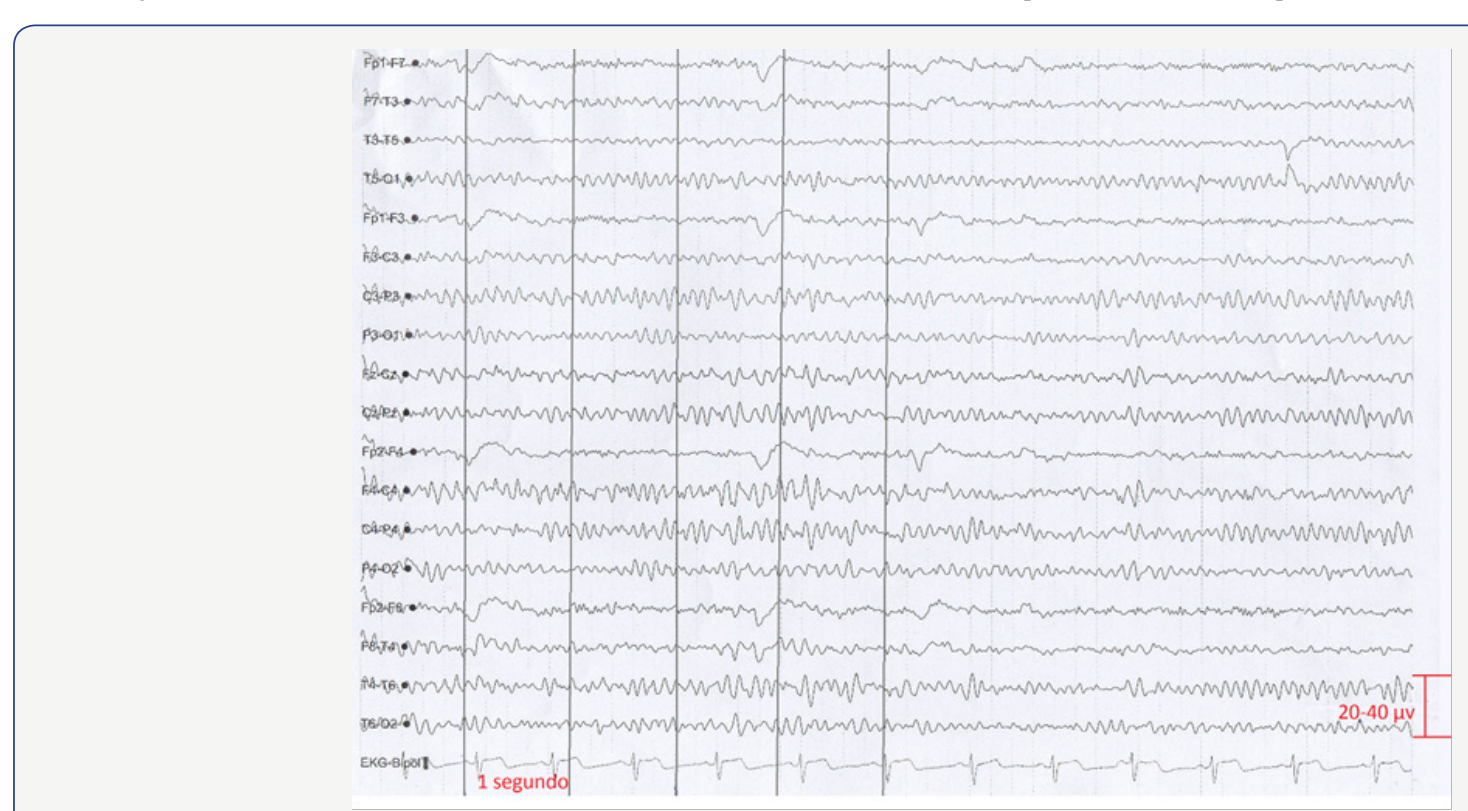

Figure 3: High filter: $30 \mathrm{~Hz}$. Low filter: $0.5 \mathrm{~Hz}$. 
Sweep: 10 milliseconds. 10 seconds per screen.

Sensitivity 7 microvolts.

II. Clinical case 2: normal EEG (Figure 3) See the absence of specific inter hemispheric calculable anomalies.

III. Clinical case 3: 36-year-old male from the Psychiatry outpatient clinic. In the tracing it is shown an EEG activity within normal limits. It is also shown a frequent and attenuated activity on voltage, with a low incidence in the (background) tracing with acute morphology which can be compatible with bitemporal mild vascular focus of low incidence in the (background) tracing, in right and left fronto-temporal region, being more noticeable on the left side. Vascular activity goes to $7 \mathrm{~Hz}$.

\section{CAT brain without any contrast: no evidence of acute intracranial pathology.}

IV. Clinical case 4: 50-year-old male from Psychiatry outpatient clinic. He has been cocaine user for several years. It is found an EEG tracing in its normal limits. It is registered a focused slight activity in the left and right hemisphere, and it is marker on left side [12]. It is also shown a slight incidence and an electric impact on the rest of the (background) tracing. We can see sharp and slow waves morphology with moderate voltage in the left frontal región; that activity slows slightly the area on which it stabilizes, at a frequency of $7 \mathrm{~Hz}$ when this patient's alpha is $9 \mathrm{~Hz}$.

\section{TAC brain without contrast: No signs of acute intracranial pathology.}

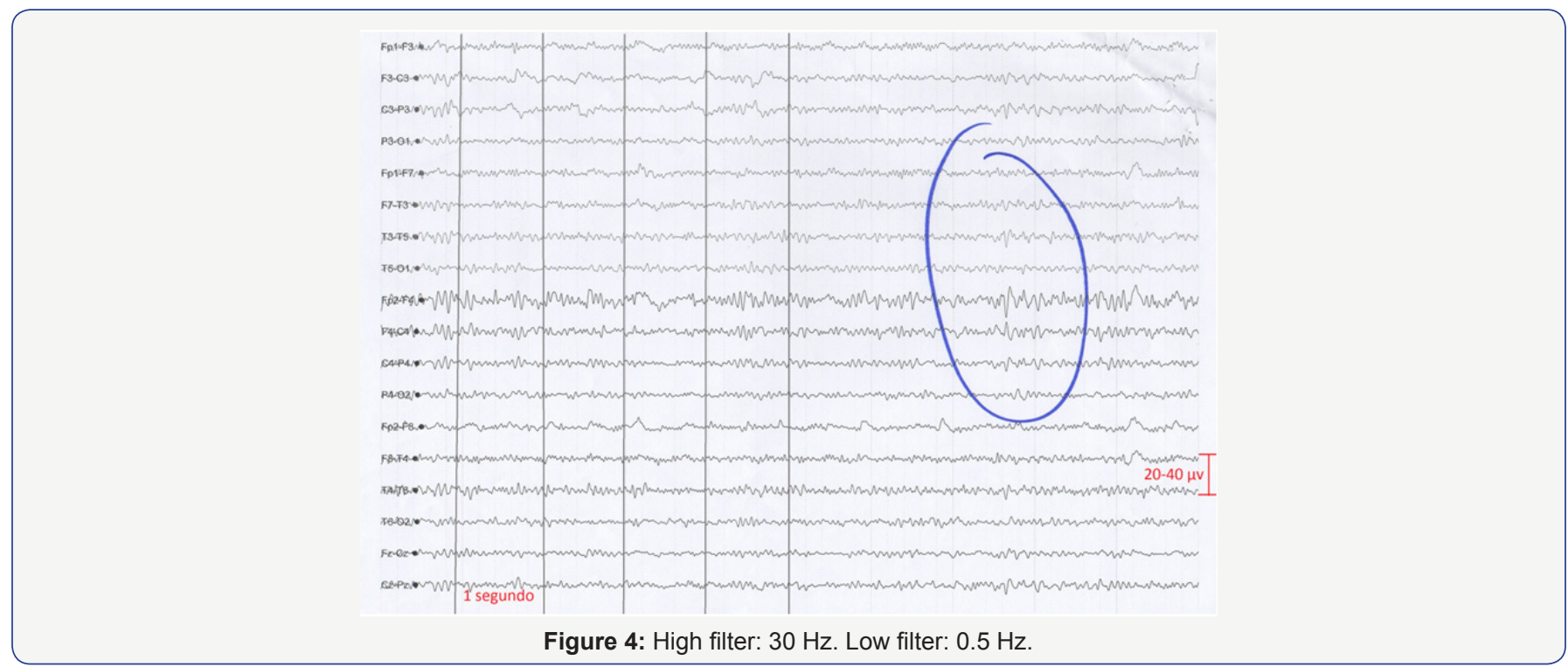

Sweep: 10 milliseconds. 10 seconds per screen.

Sensitivity 7 microvolts.

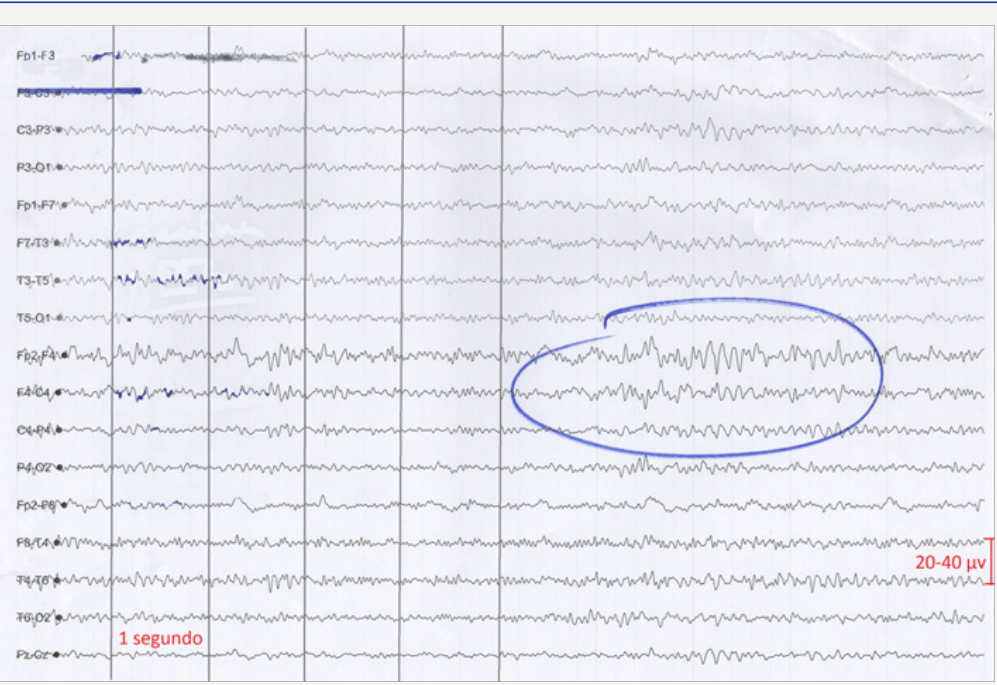

Figure 5: Filtro alto: $30 \mathrm{~Hz}$. Filtro bajo: $0.5 \mathrm{~Hz}$.

Barrido: 10 milisegundos. 10 segundos por pantalla.

Sensibilidad: 7 microvoltios. Sensitivity 7 microvolts.
High filter: $30 \mathrm{~Hz}$. Low filter: $0.5 \mathrm{~Hz}$.

Sweep: 10 milliseconds. 10 seconds per screen. 


\section{Orthopedics and Rheumatology Open Access Journal}

V. Clinical case 5: 51-year-old woman from Psychiatry outpatient clinic. It is found an EEG tracing in its normal limits. It is registered a slight focused activity in both right and left hemisphere, although it is more pronounced on right side. In addition to this, there is a slight incidence and an electric impact on the rest of the tracing, with a moderate voltage activity in the right frontal region at a frequency of $7 \mathrm{~Hz}$ when the patient's alpha is $9 \mathrm{~Hz}$. The activity lasts from 0.5 to $1 \mathrm{msec}$. Without alterations in the brain magnetic resonance imaging (MRI) scan (Figures $4 \& 5$ ).

VI. Clinical case 6: 47-year-old male from Psychiatry outpatient clinic. Cocaine user. It presents normal (background) tracing, with regional activity both in left and right hemisphere, but being more noticeable on left side. There is a moderate incidence and an electric impact on the rest of the tracing, with slow waves morphology, that slow down the area at a frequency of 5-7 Hz. The voltage is moderate in fronto-temporal region with irradiation to the left parietal area and low diffusion to the right parietal one; that activity lows down at a frequency of 5-7 Hz when the tracing (de fondo) is $9 \mathrm{~Hz}$. The activity last from 0.5 to 1 msec.

VII. Clinical case 7: 42-year-old male who is derived from Psychiatry outpatient clinic. It is observed an activity (background) with normal limits in the tracing, and also it presents diffuse beta Rhythms of probable pharmacological origin with irregular alpha rhythms. A focused, moderate and bilateral activity, mostly in left side and with a frequency of $7-8 \mathrm{~Hz}$ when the alpha goes to $10-11 \mathrm{~Hz}$. The bilateral frontal lobe is partially slowed down and with left side predominance [13-17]. These slow activities last from 0.5 to $1 \mathrm{msec}$. Without any alterations in the Cerebral RMN (Figures 6 \& 7).

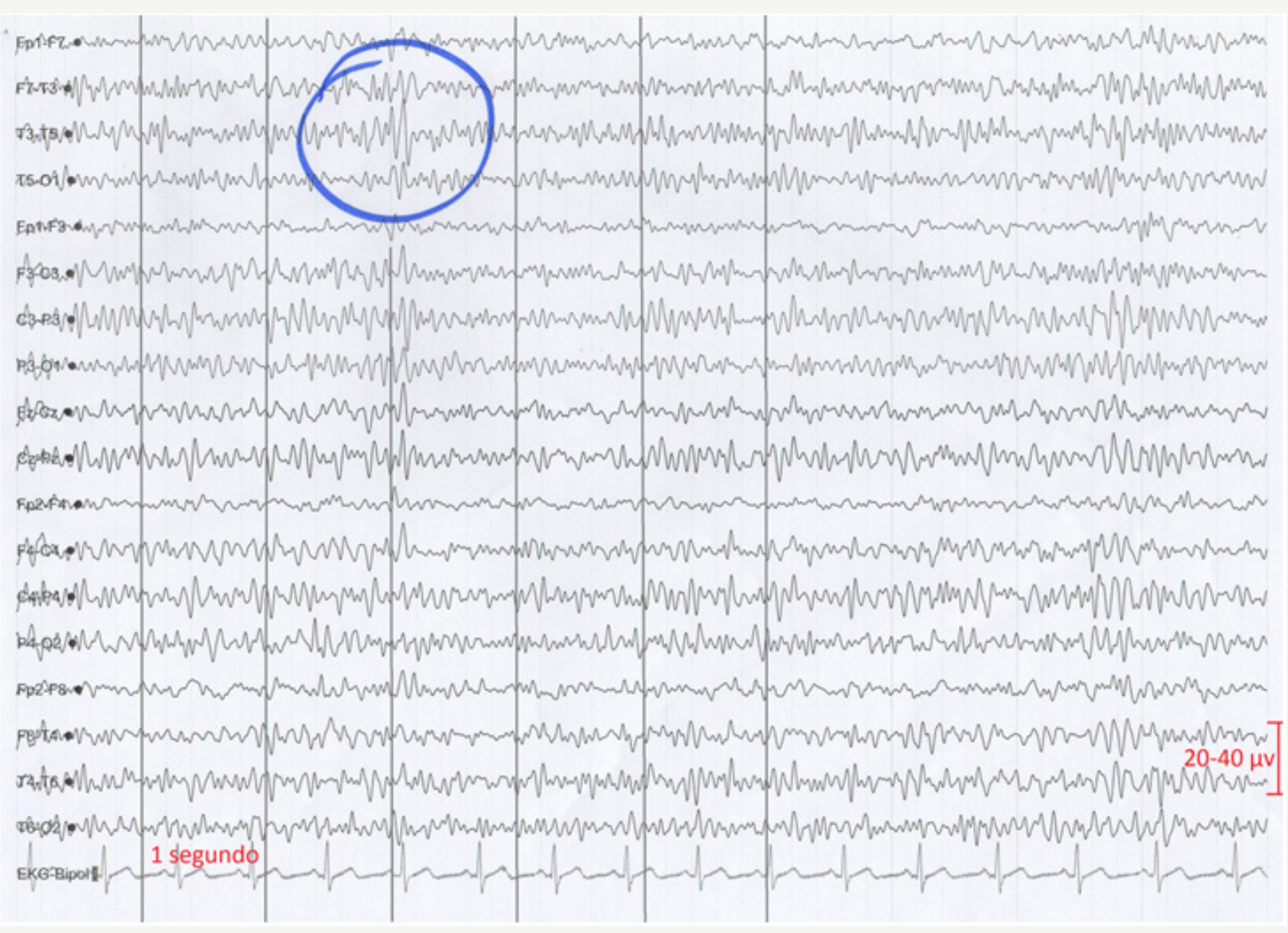

Figure 6: High filter: $30 \mathrm{~Hz}$. Low filter: $0.5 \mathrm{~Hz}$.

Sweep: 10 milliseconds. 10 seconds per screen.

Sensitivity 7 microvolts.

VIII. Clinical Case 8: a 25-year-old male is derived from the external consultation of psychiatry. Observations show an activity (background) with normal limits in the tracing. Malfunction frontal left and parietal left with frequency from
5-6 Hz. to 0.5-1 msec of duration. This activity slows down the bilateral frontal activity with left side predominance. Without alterations in the brain magnetic resonance imaging (MRI) scan (Figures 8-10). 

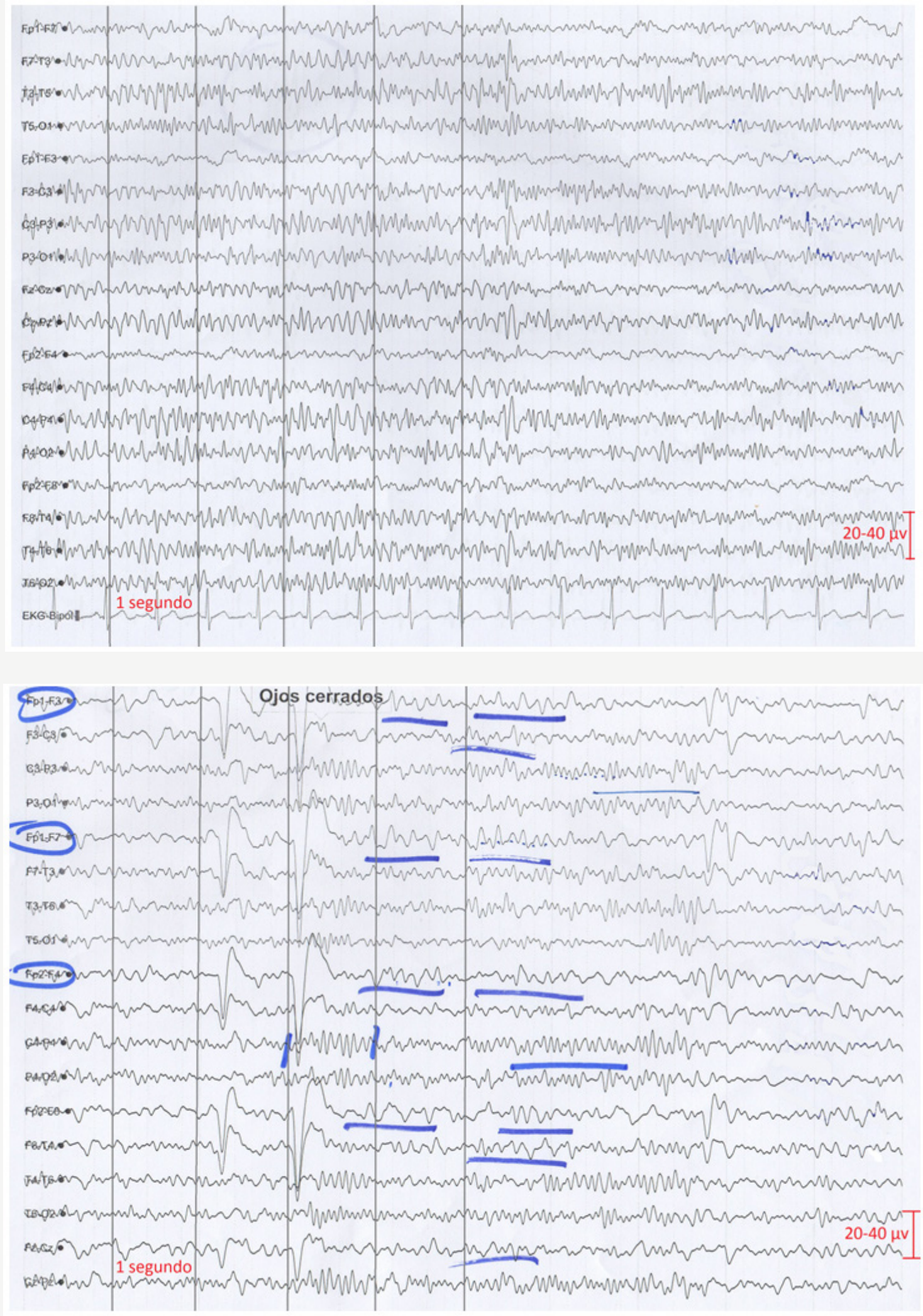

Figure 7: High filter: $30 \mathrm{~Hz}$. Low filter: $0.5 \mathrm{~Hz}$.

Sweep: 10 milliseconds. 10 seconds per screen.

Sensitivity 7 microvolts. 


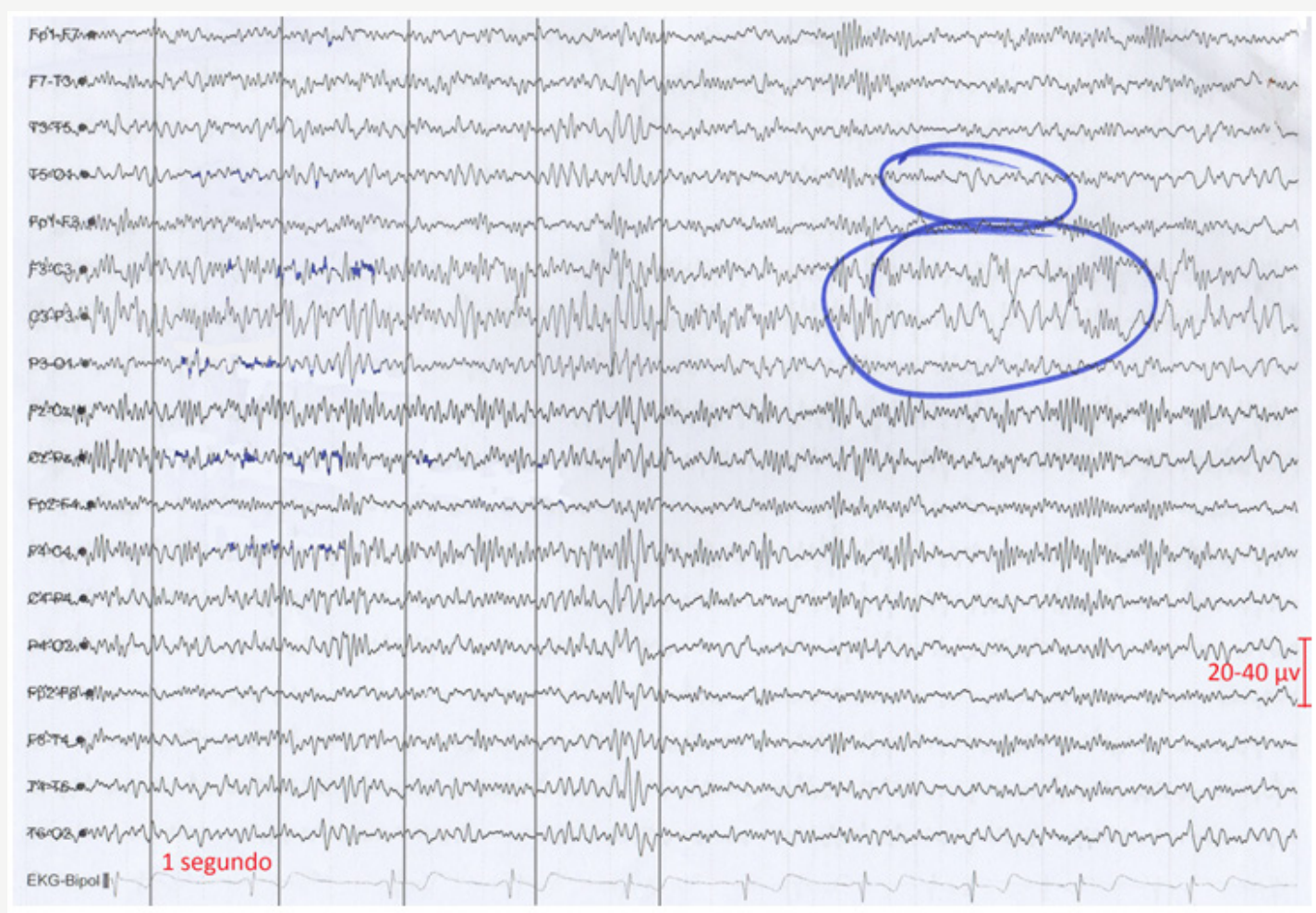

Figure 8: High filter: $30 \mathrm{~Hz}$. Low filter: $0.5 \mathrm{~Hz}$.

Sweep: 10 milliseconds. 10 seconds per screen.

Sensitivity 7 microvolts.

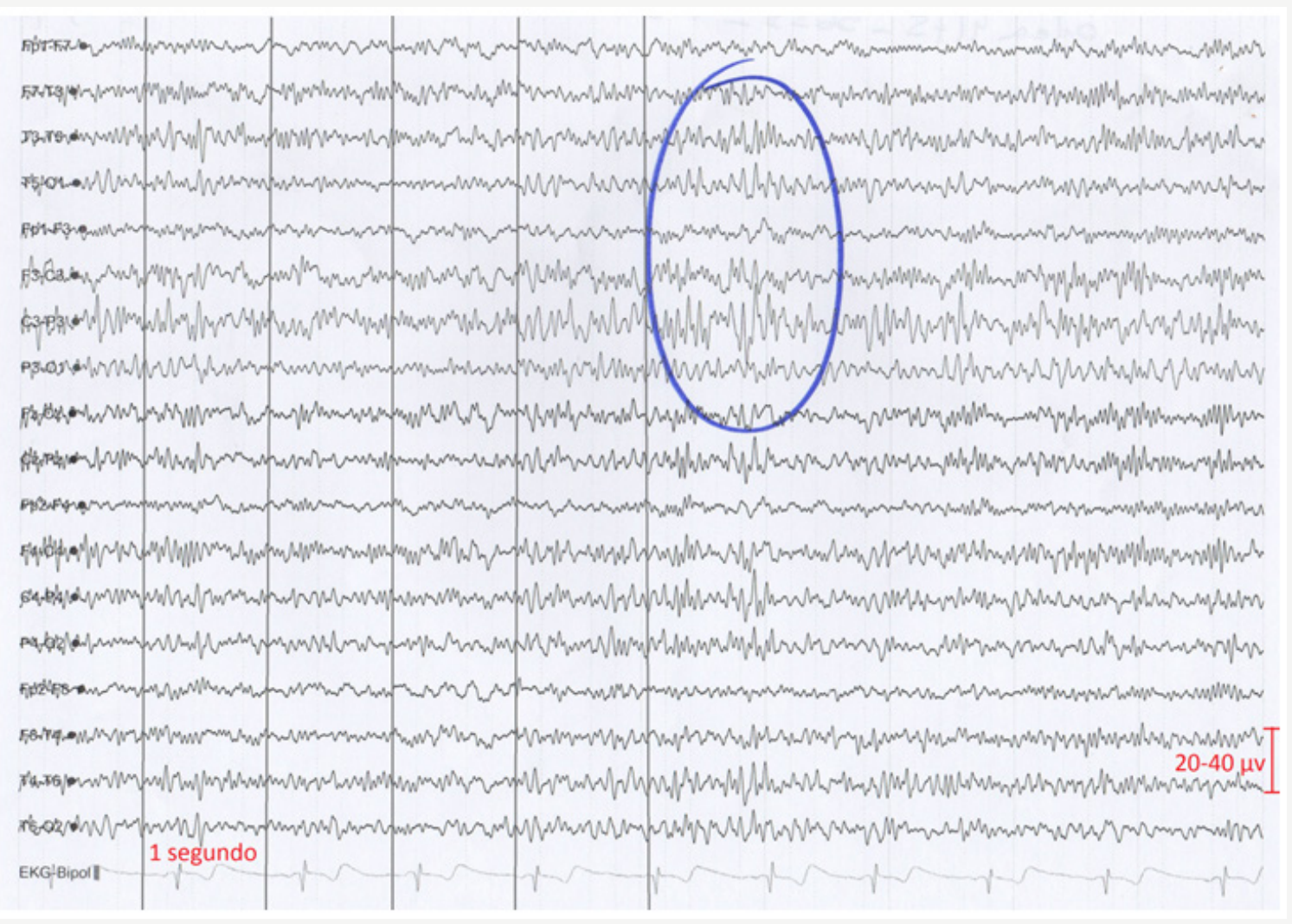




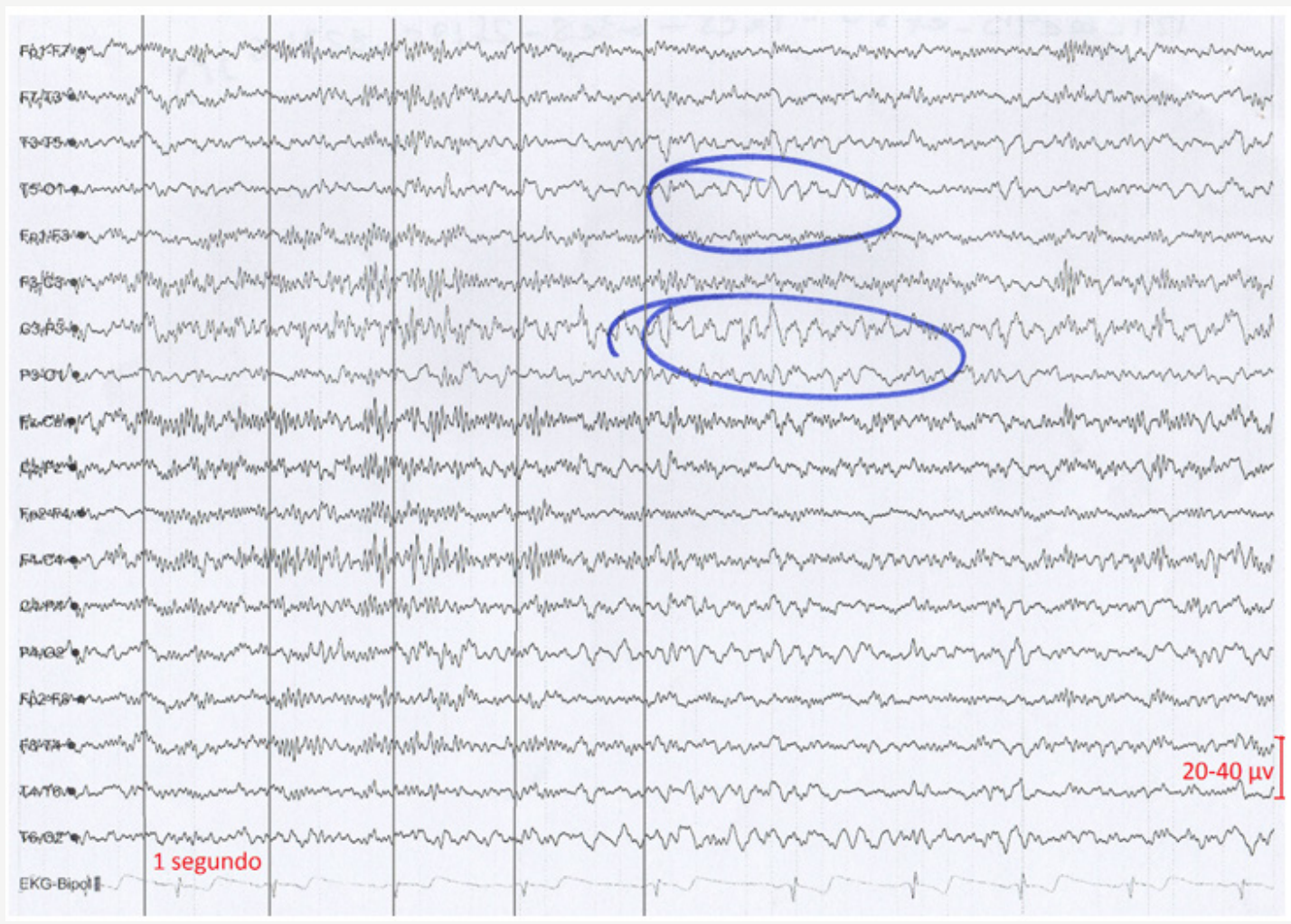

Figure 9: High filter: $30 \mathrm{~Hz}$. Low filter: $0.5 \mathrm{~Hz}$.

Sweep: 10 milliseconds. 10 seconds per screen.

Sensitivity 7 microvolts.

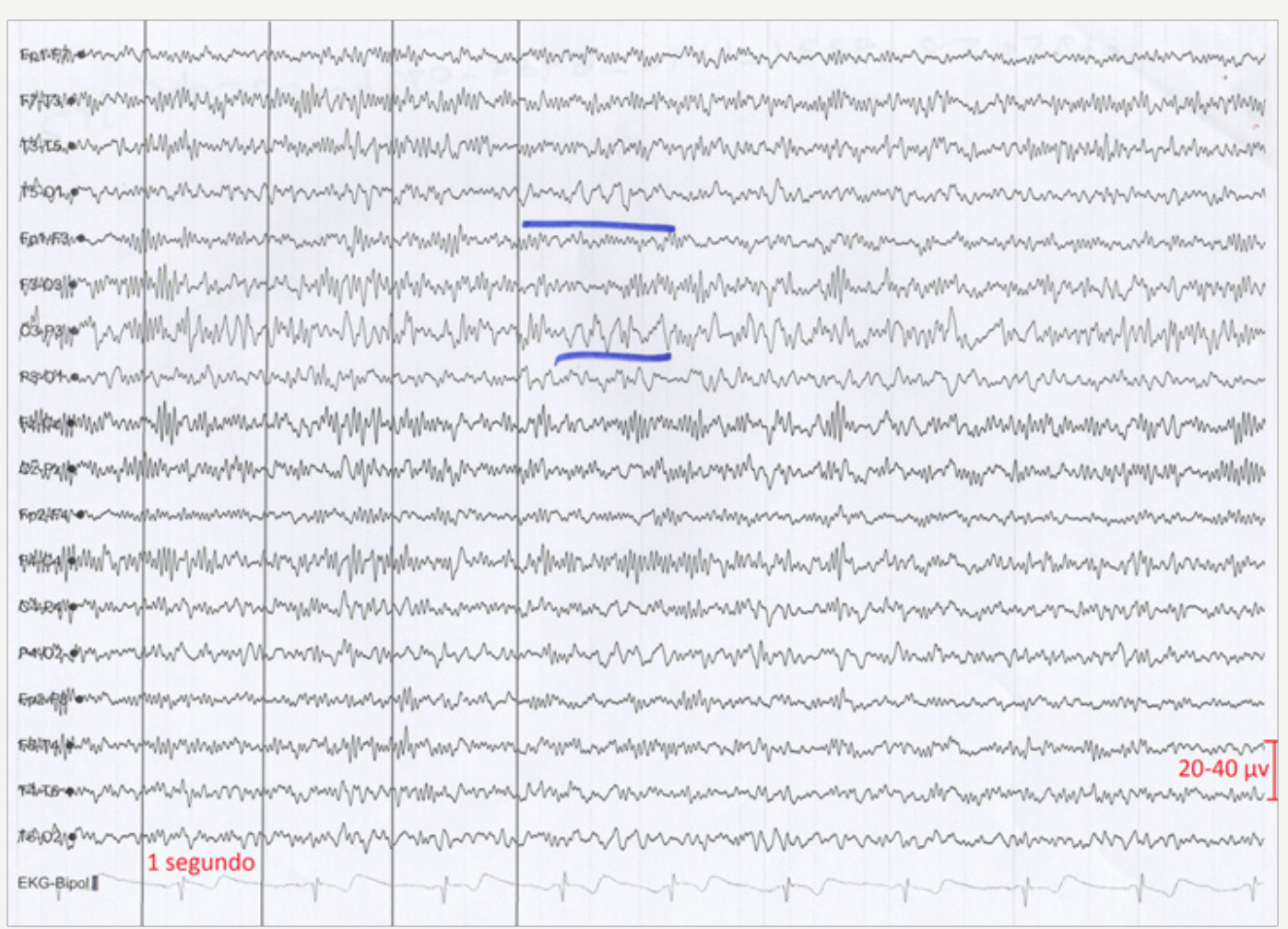

Figure 10: High filter: $30 \mathrm{~Hz}$. Low filter: $0.5 \mathrm{~Hz}$. 
Sweep: 10 milliseconds. 10 seconds per screen.

Sensitivity 7 microvolts.

IX. Clinical case 9: 30-year-old male derived from the external consultation of psychiatry. Normal tracing of $9 \mathrm{~Hz}$ with a slow activity in the left front-temporal región with a frequency of $7 \mathrm{~Hz}$. They present common information to the previous EEG cocaine consumers. Normal skull TAC (Figure 11)

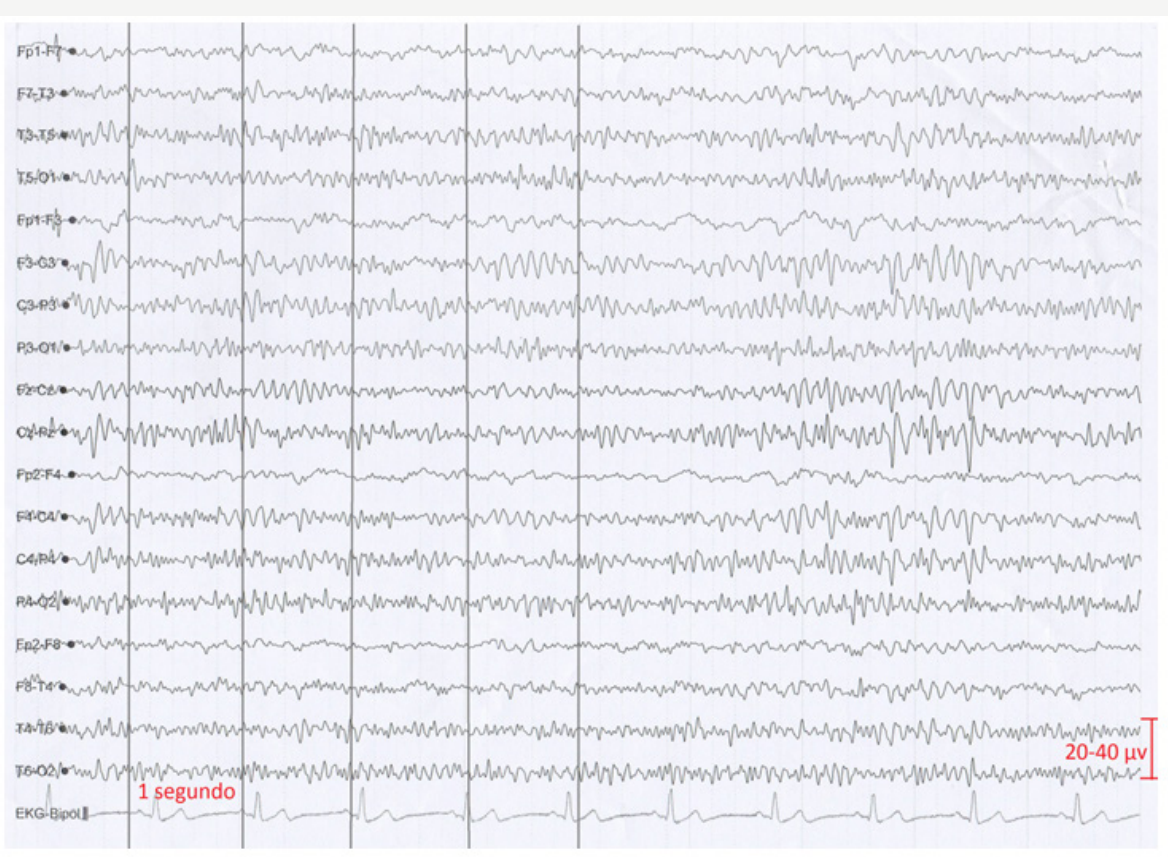

Figure 11: High filter: $30 \mathrm{~Hz}$. Low filter: $0.5 \mathrm{~Hz}$.

Sweep: 10 milliseconds. 10 seconds per screen.

Sensitivity 7 microvolts.

X. Clinical case 10: 34-year-old male derived of
Psychiatry outpatient clinical. We can observe a dysfunction in bilateral front-temporal region. There is not any alterations in the Cerebral RMN (Figure 12).

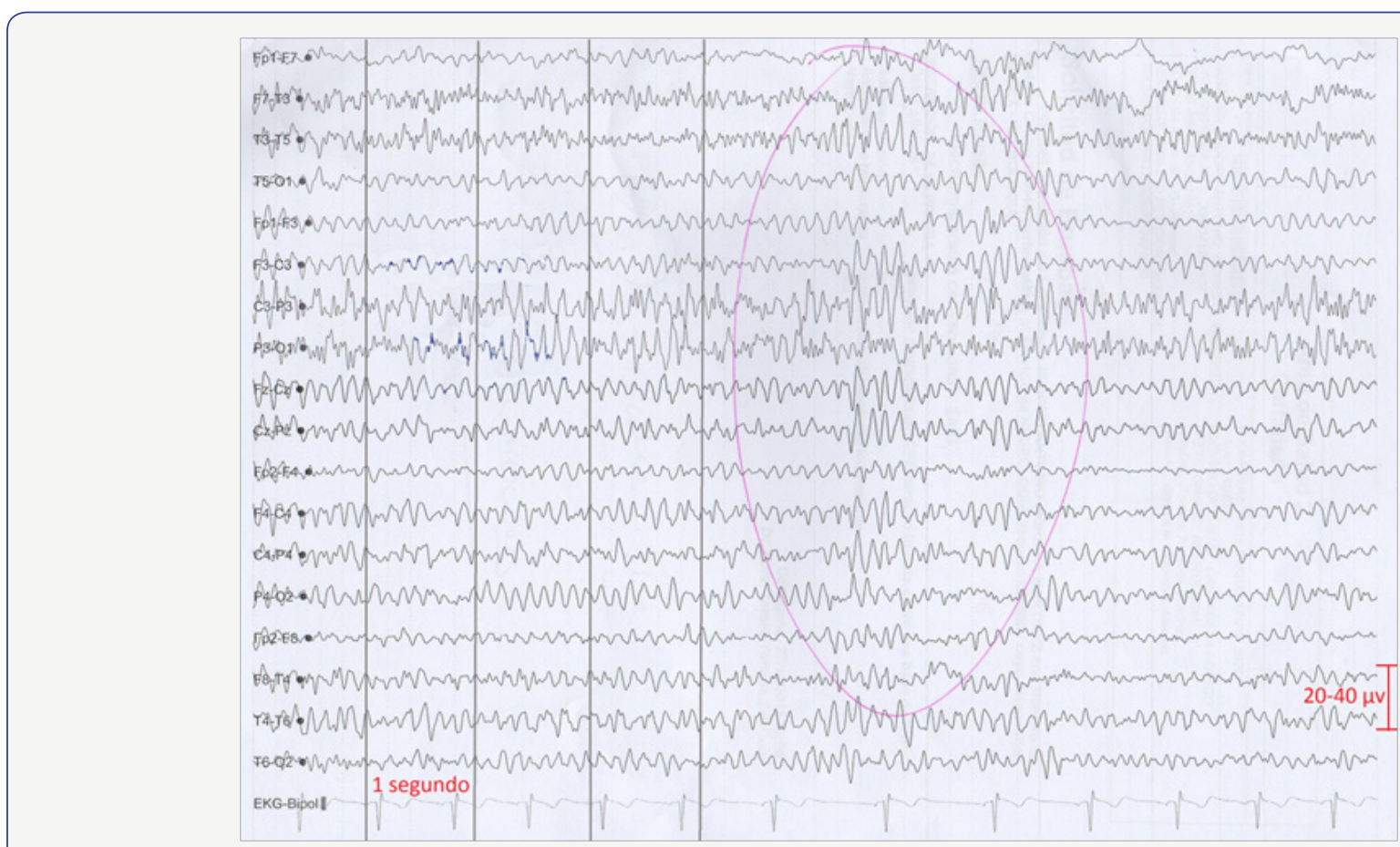

Figure 12: High filter: $30 \mathrm{~Hz}$. Low filter: $0.5 \mathrm{~Hz}$. 
Sweep: 10 milliseconds. 10 seconds per screen.

Sensitivity 7 microvolts.

XI. Clinical case 11: 40-year-old male from the psychiatry outpatient clinic. Violent conduct and cocaine user. We notice a brain bioelectric activity which consists of a mixture of frequencies of $10 \mathrm{~Hz}$ with parieto-occipital Alpha rhythm, and fast rhythms in previous areas. There is a dysfunction in right front-temporal region, $7 \mathrm{~Hz}$ frequency that radiates a little to the left hemisphere. Without any alterations in brain MRI.

XII. Clinical case 12: 27-year-old male from psychiatry outpatient clinic. Focused and moderate activity and with moderate incidence in the tracing (background ) We can see a focused activity in right front-parieto-temporal region, of sharp morphology that slows regionally the tracing, and with a frequency of 5-6 Hz, clearly more focused in the right hemisphere, in parieto-temporal region. We can see a slight incidence and an electric impact in the rest of the tracing (background), with sharp and slow waves morphology, moderate voltage involved in F4, C4., P4, T4, T6 regions and with mild diffusion to the adjacent C3-P3 area, activity with nonspecific morphology for epilepsy, with the same reactivity in the tracing (background), that excels partially and constitute a slight inter-hemispheric asymmetry. The ELI with $5-10 \mathrm{~Hz}$ generates a very characteristic drug in this type of patients [18-21]. The HV slows down in a physiological way the (background) tracing. Without alterations in brain MRI (Figures 13 \& 14).

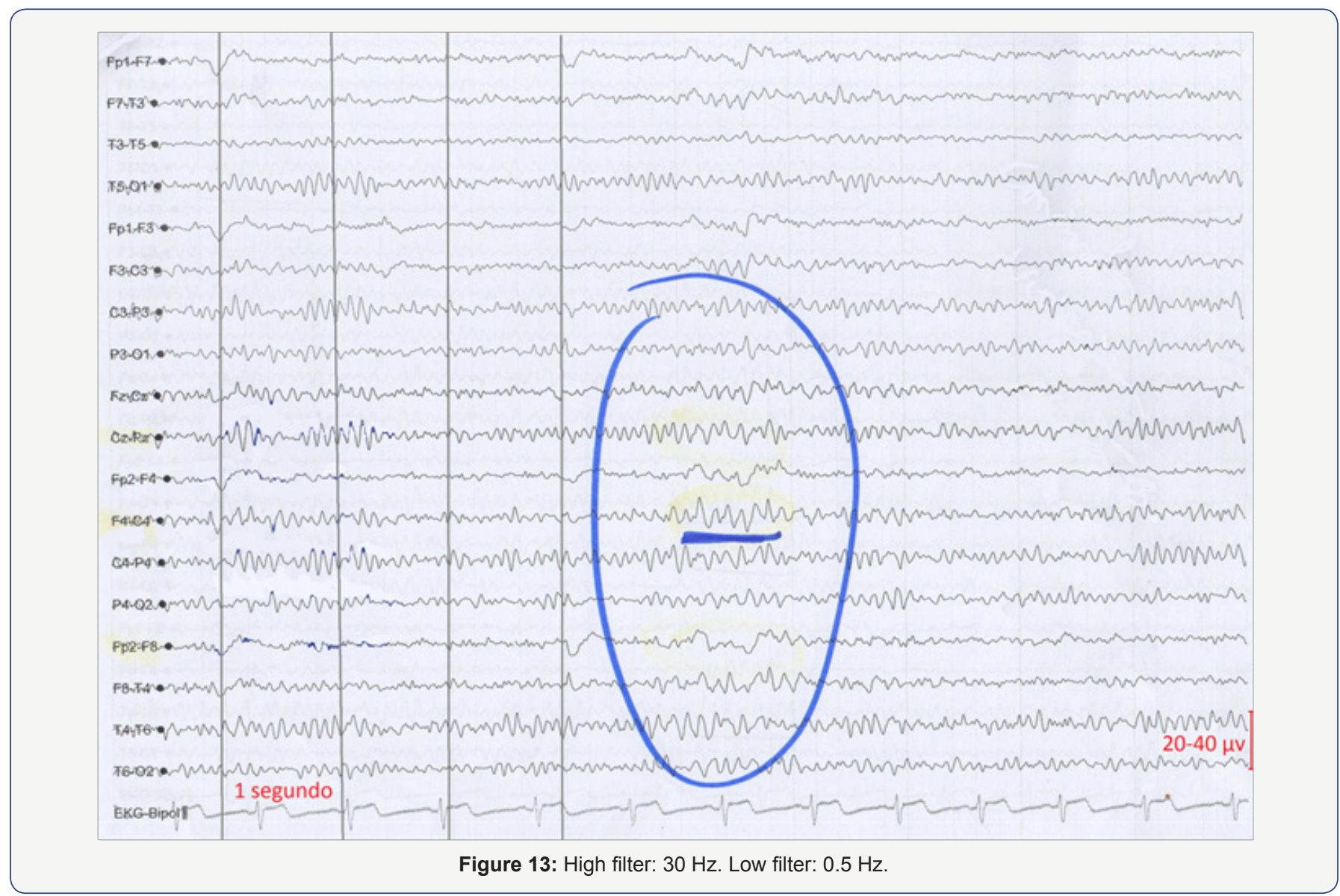

Sweep: 10 milliseconds. 10 seconds per screen.

Sensitivity 7 microvolts.

XIII. Clinical case 13: 48-year-old woman who is derived from psychiatry outpatient clinic. Normal brain bioelectric activity, which consists of a diffused beta rythm in relation to an ontogeny caused by benzodiazepines. There is not any brain RMN alterations.

XIV. Clinical case 14: 24 year-old male derived from Psychiatry outpatient clinic. He is a prior ethyl user, cocaine and cannabis user, nictameral deprivation. We can see Irritative EEG signs of focused character in both right and left front-central region. There is a tendency to generalize with hyperventilation. Normal caneal NMR. Signal Intensity and morphology changes in temporal lobes are not detected. Periventricular or peripheral alterations are not found either.

XV. Clinical case 15: 19-year-old male derived from psychiatry outpatient clinic. We can notice a slight slowing down in the EEG tracing (background) which is compatible 


\section{Orthopedics and Rheumatology Open Access Journal}

with a mild grade encephalopathy. This (background) rhythm sometimes alternates with faster periods in the tracing (background) with an irregular and scarce alpha
8-9 $\mathrm{Hz}$, that means a progress in the cerebral bioelectrical tracing.

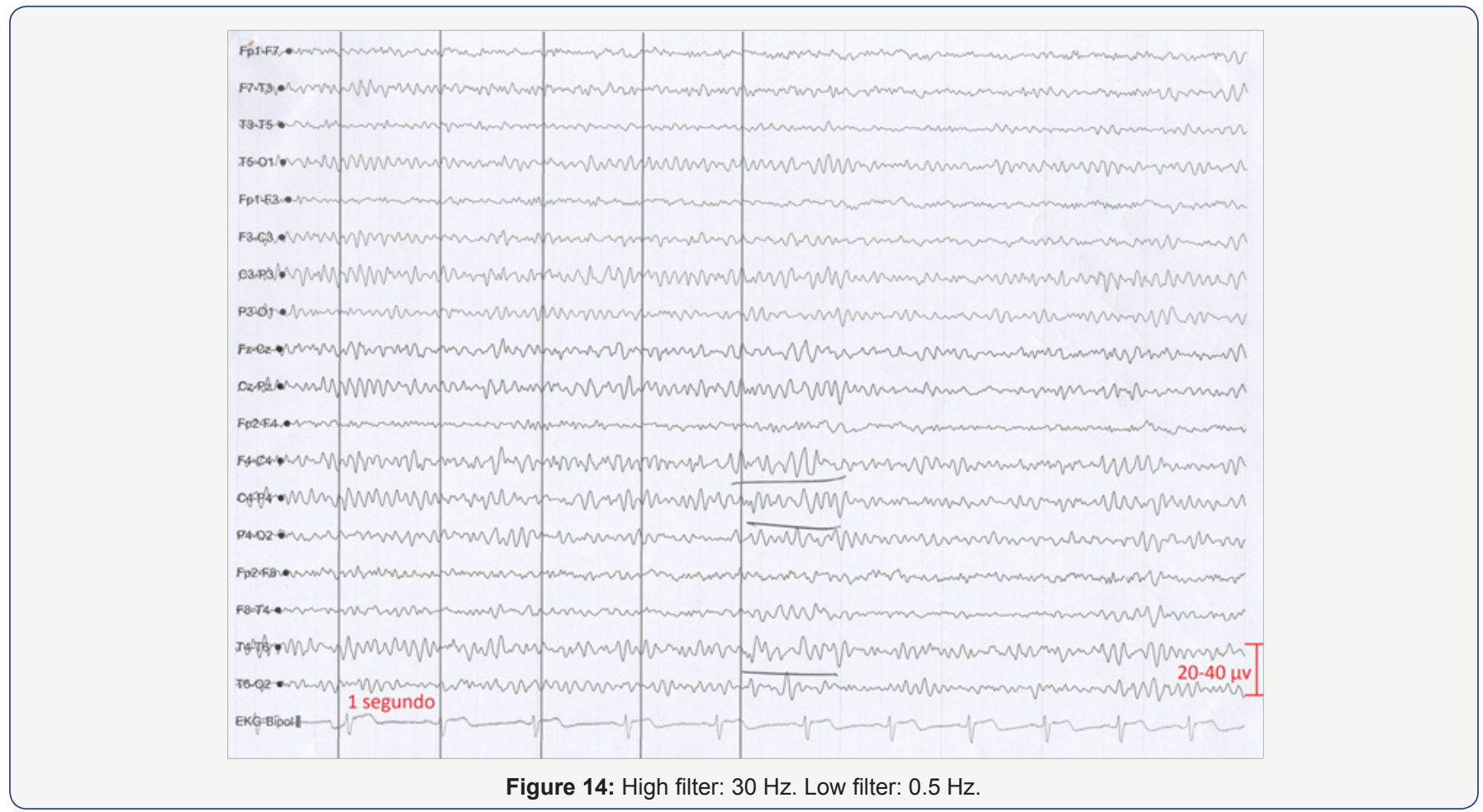

We can see a focused and attenuated activity with scarce voltage. This specific morphology means epilepsy, and it is found in left front-parieto-temporal left region (F3 - F7-P3 - T3-T5 P4) and it is slightly focused and constituted by sharp and slow waves with attenuated voltage and a specific morphology that means epilepsy [22-24]. The duration is $0.5-1$ seg. This activity appears both in the ocular opening and closing which spreads partially to the adjacent areas of the right hemisphere and which is compatible with CPC against partial epileptic focus a second time widespread.

\section{Cranial RM: without evidence of significant pathological finds.}

Table 1: Chart of affected areas in EEG.

\begin{tabular}{|c|c|}
\hline AFFECTED AREAS IN EEG & № OF PATIENTS \\
\hline Left frontal & 1 \\
\hline Right frontal & 1 \\
\hline $\begin{array}{c}\text { Left Predominance Front } \\
\text { Bilateral }\end{array}$ & 2 \\
\hline Left Front-Temporal & 1 \\
\hline Right Front-Temporal & 3 \\
\hline Front-Temporal-Bilateral & 1 \\
\hline Left Front-Parietal & 1 \\
\hline
\end{tabular}

\begin{tabular}{|c|c|}
\hline Right Front-Parietal-Temporal & 1 \\
\hline Left Front-Parietal-Temporal & 1 \\
\hline Front-Central Bilateral & 1 \\
\hline
\end{tabular}

Discrete asymmetry with temporal masts and a right higher volume, like the only find (this find is visualized in a high percentage in normal population) (Table 1).

Results (Figure 15)

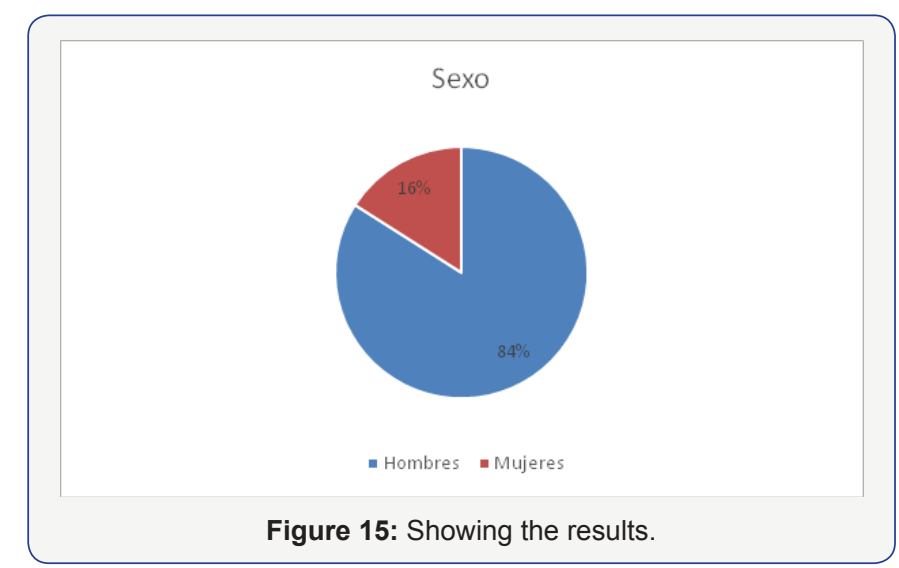

In our study there is an $84 \%$ male and a $16 \%$ female, aged between 19 and 51 years old, and the average is 36 years old.

None clinical case out of all 13 contains any alteration in cerebral nuclear magnetic resonance (RMN) (Figure 16). 


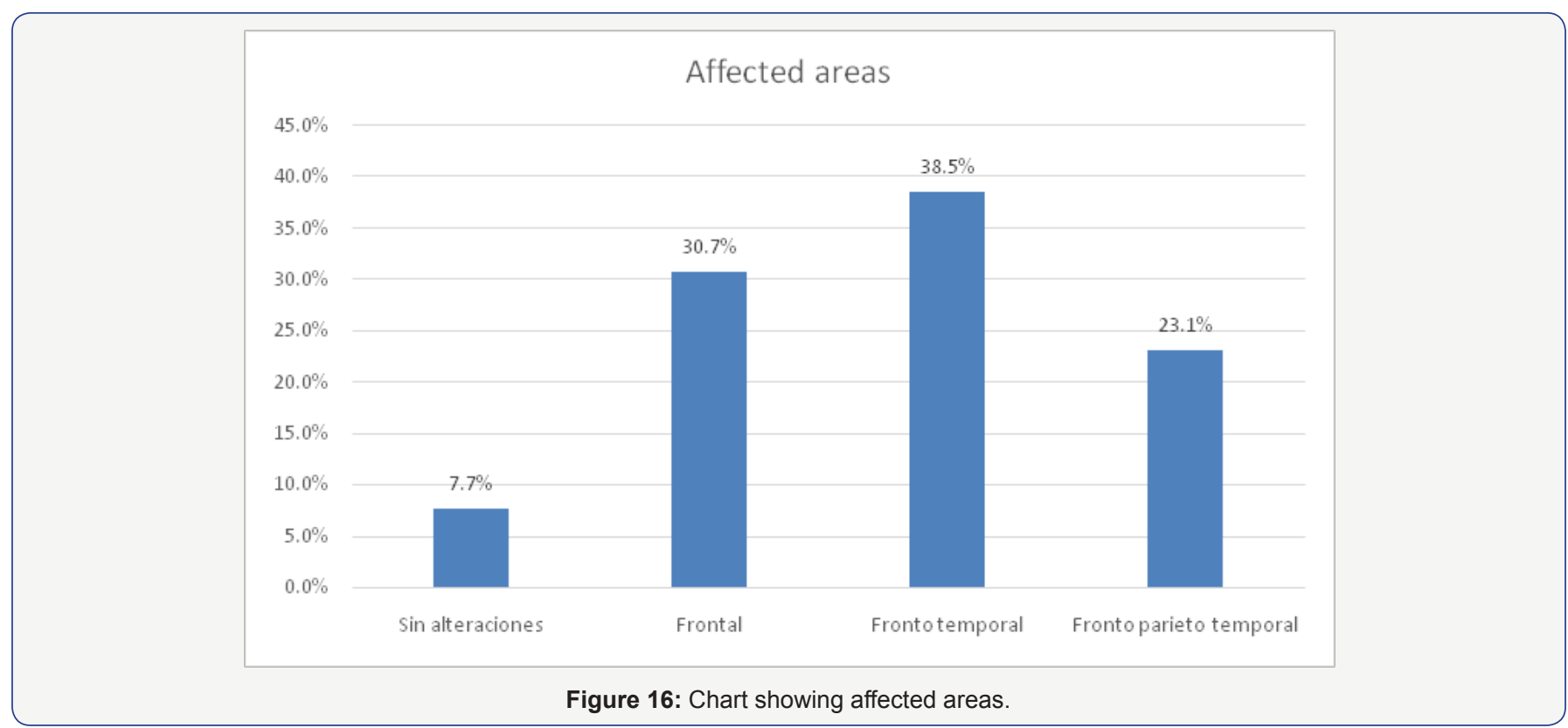

$84.6 \%$ out of the electroencephalograms of our study reveal the existence of minimum cortical dysfunctions in frontal areas with more or less spread to adjacent cortical areas. The most affected area with a $38.5 \%$ is the front-temporal one with higher predominance of the left hemisphere. These slow activities are often registered at a $7 \mathrm{~Hz}$ frequency when the normal (background) tracing is $9-10 \mathrm{~Hz}$. That activity lasts from 0.5 to 2 msec (Figure 17).

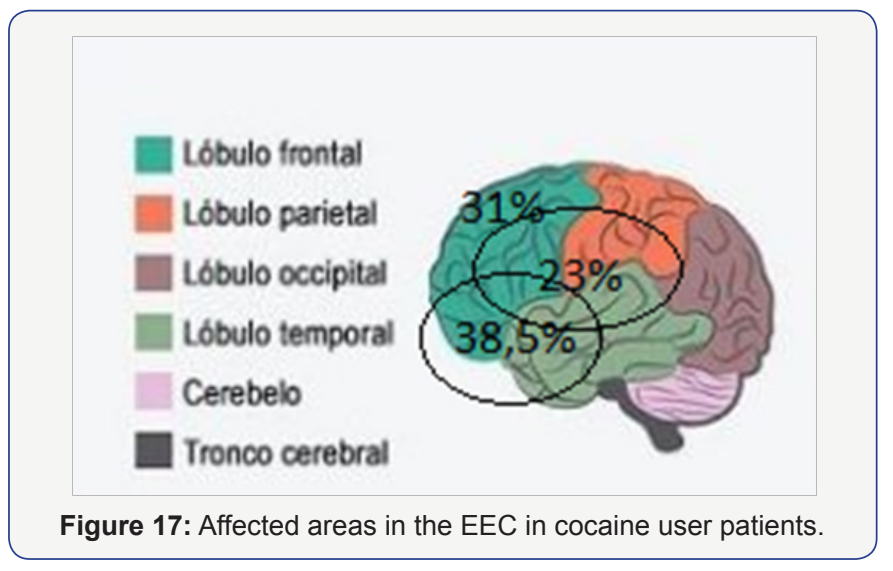

\section{Conclusion}

Frontal area is responsible for self-control, so an alteration in frontal lobe causes alteration of the executive functions, mental deterioration, personality and deshinbition behavior alterations.

Images of the brain show a decrease in dopamine receptors (D2) in a person's brain with cocaine addiction in comparison to someone who does not consume drugs.

These minimum dysfunctional injuries support the theory, which is so often seen in the literature, that not all pathology is structural, but there is pathology with minimum dysfunctional or metabolic lesions without an associated anatomopathological substrate. That is why our study defines the importance of the EEG in the diagnosis of dysfunctional disorders like ADHD, schizophrenia, and these 13 chronic patients of cocaine with MML anodyne, as we have seen.

\section{References}

1. Barkley RA (1997) Attention-deficit/hyperactivity disorder, selfregulation, and time: toward a more comprehensive theory. J Dev Behav Pediatr 18(4): 271-279.

2. Fliers EA, de Hoog ML, Franke B, Faraone SV, Rommelse NN, et al. (2010) Actual motor performance and self-perceived motor competence in children with attention-deficit hyperactivity disorder compared with healthy siblings and peers. J Dev Behav Pediatr 31(1): 35-40.

3. Blum K, Kozlowski (1990) influcencia del etanol y neuromoduladores. un modelo de cascada de la recompensa. Emn. Ollat H, Parvez S, Parvez $\mathrm{H}$, editores; el alcohol y el comportamiento, aspectos basicos y clinicos , progreso en la investigación del alcohol.

4. Steger J, Imhof K, Steinhausen H, Brandeis D (2000) Brain mapping of bilateral interactions in attention deficit hyperactivity disorder and control boys. Clin Neurophysiol 111(7): 1141-1156.

5. Li F, He N, Li Y, Chen L, Huang X, et al. (2014) Intrinsic brain abnormalities in attention deficit hyperactivity disorder: a restingstate functional MR imaging study. Radiology 272: 514-523.

6. Carmona S, Vilarroya O, Bielsa A, Trèmols V, Soliva JC, et al. (2005) Global and regional gray matter reductions in ADHD: a voxel-based morphometric study. Neurosci Lett 389(2): 88-93.

7. Alvarez JA, Emory E (2006) Executive Function and the Frontal Lobes: A Meta-Analytic Review. Neuropsychol Rev 16(1): 17-42.

8. De La Fuente A, Xia S, Branch C, Li X (2013) A review of attentiondeficit/hyperactivity disorder from the perspective of brain networks. Front Hum Neurosci 7: 192.

9. Barry RJ, Clarke AR, Johnstone SJ (2003) A review of electrophysiology in attention-deficit/hyperactivity disorder: I. Qualitative and quantitative electroencephalography. Clin Neurophysiol 114(2): 171183.

10. Frey S, Petrides M (2000) Orbitofrontal cortex: a key prefrontal region for encording information. Proc Natl Acad Sci U S A 97(15): 8723-8727. 
11. Blum K, Kozlowski (1990) influcencia del etanol y neuromoduladores. un modelo de cascada de la recompensa. Emn. Ollat H, Parvez S, Parvez $\mathrm{H}$, editores; el alcohol y el comportamiento, aspectos básicos y clínicos, progreso en la investigación del alcohol.

12. Grafman J, Holyoak K, Boller F (1995) Structure and functions of the human prefrontal cortex. Ann N Y Acad Sci 769: 1-411.

13. Antoine Bechara, Hanna Damasio, Antonio R Damasio (2000) Emotion, decisión - making and the orbitofrontal cortex. Cereb Cortex 10(3): 295-307.

14. G Arbonés, A Carbajal, B Gonzalvo, M González-Gross, M Joyanes (2003) Nutrición y recomendaciones dietéticas para personas mayores. Grupo de trabajo "Salud Pública" de la Sociedad Española de Nutrición (SEN) Revista Nutrición Hospitalaria 18(3): 109-117.

15. Bastos A, González R, Molinero O, Salguero del Valle A (2005) Obesidad, nutrición y actividad física. Revista Internacional de Medicina y Ciencias de la Actividad Física y el Deporte 5(18): 140-143.

16. Cruz AJ, otros (1999) Nutrición hospitalaria en el anciano. Revista Alimentación, nutrición y salud 6(1): 7-18.

17. C0uervo M, otros (2009) Comparativa de las Ingestas Dietéticas de Referencia (IDR), de los diferentes países de la Unión Europea, de Estados Unidos (EEUU) y de la Organización Mundial de la Salud (OMS). Revista Nutrición Hospitalaria 24(4): 384-414.

\section{This work is licensed under Creative}

DOI: 10.19080/OROAJ.2017.04.555643
18. Garay J, Burdeos De Garay MF (2004) Estudio epidemiológicos internacionales sobre envejecimiento: revisión actualizada de los principales estudios. Revista Geriátrika 10(2).

19. Genua M (2001) Nutrición y valoración del estado nutricional en el anciano. Matia Fundazioa 6(12): 1-21.

20. Martín ML, Moreiras O, Carbajal A (2010) La actividad física como indicador de la caridad de vida en los ancianos. Revista multimedia Gerontology 10(1): 23-38.

21. Meléndez A (2008) Actividades Físicas para Mayores. En: Las razones para hacer ejercicio pp. 51-70.

22. Rodrigo AP (2011) Los cambios fisiológicos como factores de riesgo para la desnutrición en el anciano. En J.C. García y J.B. Rivero (Eds) Manual de atención al anciano desnutrido en el nivel primario de salud pp. 63-75.

23. Ruiz-López MD, Artacho R (2010) Nutrición y envejecimiento. En: Tratado de nutrición. Nutrición humana y salud (pp. 320-343). Madrid, España; Ediciones Médica Panamerica.

24. Ruiz-López MD, Artacho R, López M (2000) Recomendaciones nutricionales para los ancianos.

\section{Your next submission with Juniper Publishers} will reach you the below assets

- Quality Editorial service

- Swift Peer Review

- Reprints availability

- E-prints Service

- Manuscript Podcast for convenient understanding

- Global attainment for your research

- Manuscript accessibility in different formats

(Pdf, E-pub, Full Text, Audio)

- Unceasing customer service

Track the below URL for one-step submission https://juniperpublishers.com/online-submission.php 